\title{
ArcheoSciences
}

Revue d'archéométrie

33 (suppl.) | 2009

Mémoire du sol, espace des hommes

\section{Global survey of the frontiers of the Roman Empire in Southern Germany, UNESCO World Heritage Site}

Jörg W. E. Fassbinder

\section{OpenEdition}

1 Journals

Electronic version

URL: https://journals.openedition.org/archeosciences/1277

DOI: 10.4000/archeosciences. 1277

ISBN: 978-2-7535-1599-4

ISSN: $2104-3728$

Publisher

Presses universitaires de Rennes

Printed version

Date of publication: 30 October 2009

Number of pages: $55-58$

ISBN: 978-2-7535-0943-6

ISSN: 1960-1360

\section{Electronic reference}

Jörg W. E. Fassbinder, "Global survey of the frontiers of the Roman Empire in Southern Germany, UNESCO World Heritage Site", ArcheoSciences [Online], 33 (suppl.) | 2009, Online since 30 October 2011, connection on 01 February 2022. URL: http://journals.openedition.org/archeosciences/1277 ; DOl: https://doi.org/10.4000/archeosciences. 1277 


\title{
Global survey of the frontiers of the Roman Empire in Southern Germany, UNESCO World Heritage Site
}

\author{
Jorg W. E. FASSBINDER
}

Key words: Magnetic prospecting, Airborne laser scanning, Roman Limes, Roman forts, Bavaria.

\section{INTRODUCTION}

The Roman Limes with a length of $550 \mathrm{~km}$ is the largest archaeological site of Europe as well as the largest monument of the Roman period. In July 2005, it was decided that the Limes and its interrelated archaeological sites, together with Hadrian's Wall in England, would be a component of a "Trans-National World Heritage" project taking the name "Frontiers of the Roman Empire". Along the Limes more than 120 Roman forts, military camps and pickets, as well as 900 watchtowers have been discovered. Since 1892 the "Reichs-Limes-Kommission" has traced the remains of the path, the walls and the buildings associated with the Limes. However, in many areas sometimes even the exact location of the Limes itself remains unknown. More so the inner structures of Roman forts and military camps were sometimes difficult to find, in particular with regard to barracks, palisades or other wooden structures. The application of aerial archaeology, airborne laser scanning (ALS), high definition magnetic and resistivity prospecting gives a broad picture of the current state of preservation of these sites.

\section{Archaeological background}

In 1892 the "Reichs-Limes-Kommision" started its work with a survey and trench excavation of buildings and structures associated with the Upper German-Raetian Limes. Nearly all known Roman forts were partly excavated with archaeologists tracing mainly stone foundations. Excavation techniques at the time were not sophisticated enough to find and to recognize the remnants of wooden structures inside the Roman forts. Therefore, almost nothing is known of the ground plan of the soldiers' barracks that were made mainly of wood. Moreover, many forts also remained undiscovered. The establishment of the aerial archaeological prospecting section of the Bavarian State Department of Monuments and Sites in the 1970s was a big step in completing the mapping of the Limes. Air photography was limited, however, to sites in the open landscape. Airborne laser scanning now complements the prospection, enabling unknown traces even under forest cover to be recognized and recorded.

\footnotetext{
* Bavarian State Department. of Monuments and Sites, Hofgraben 4, 80539 Munchen, Germany. (joerg.fassbinder@blfd.bayern.de)
} 


\section{Magnetometry OF THE LiMES, ROMAN FORTS AND ASSOCIATED STRUCTURES}

Although numerous Roman forts are already overbuilt by modern villages and are partly destroyed, there are 15 forts still open to geophysical prospection. Magnetometry is the most successful and cost-effective geophysical method for a detailed mapping of such large areas in reasonable time. In order to reach the highest possible sensitivity combined with the maximum speed of prospection we chose the Scintrex Smartmag SM 4G-Special caesium magnetometer in the so called duo-sensor configuration. Diurnal variations are reduced to the mean value of all data from the $40 \times 40 \mathrm{~m}$ grid (Becker, 1999).

The results show that magnetic prospecting delivers not only information about wooden and stone structures, but it can result in detailed maps of these large archaeological sites (Fig. 1). It is possible not only to trace and recognize the type, but also the degree and nature of the utilisation. For example, the results can be used to solve the question of whether the barracks were used by foot soldiers or by cavalry as well; moreover, it allows the calculation of the force level of the combat units. These higher-than-average good results of magnetic prospecting are also due to the fact that almost all military camps of this period were destroyed by violence and conflagrations. In conjunction with the low magnetic signal of the limestone geological bedding, this explains the high contrast and the resulting clear magnetic image with dynamics of $\pm 20,0 \mathrm{nT}$.
For the interpretation we combined the early findings and the old excavation maps published by the "Reichs-LimesKommission" (Fabricius et al., 1884-1937) with our prospection results. In this way it was not only possible to complete the old ground-maps, but to give an overall archaeological interpretation of the site (see Fig. 2). Furthermore, we have also obtained detailed information about the actual situation and the preservation of the archaeological remains underground (Fassbinder, 2008).

\section{Airborne Laser Scanning}

From 2006 to 2008 the entire Bavarian part of the Upper German-Raetian Limes was covered by an airborne laser scan. The raw data of the digital terrain model (DTM) covered a strip of a few dozen 100 meters along the limes. Data processing under different aspects permitted the discovery of several previously unknown watchtowers (Fig. 3) and the finding of interrelated stone quarries (Kerscher, 2008). Further processing will allow a rough estimate of the height of the wall.

\section{Conclusion}

The Roman Limes and all associated structures were declared a UNESCO World Heritage site in 2005 making archaeological excavation no longer a suitable tool for further research on these archaeological sites and monuments.

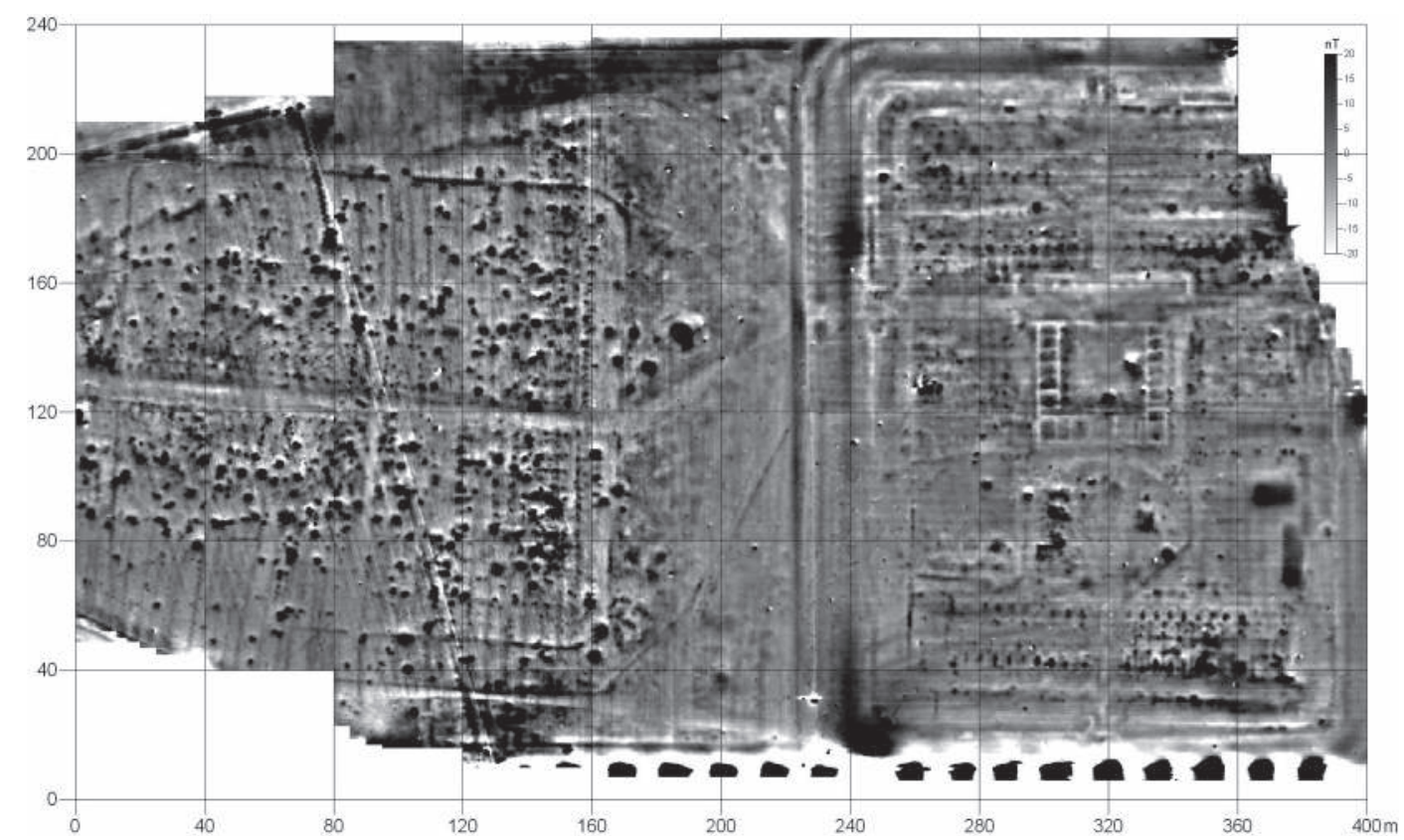

Figure 1: Theilenhofen. Magnetogram of the Roman fort. The ground plan of a typical Roman fort constructed on stone foundations (right side) as well as an older fort consisting simply of wooden barracks later overbuilt by a civil settlement (left side). Dynamics +/-20 Nanotesla, in 256 greyscales, grid size 40 x 40 meters, sampling rate interpolated to $25 \mathrm{x}$ $25 \mathrm{~cm}$. 
Figure 2: Theilenhofen. Archaeological map based on the interpretation of magnetometer data combined with findings of archaeological excavations published by the ReichsLimes-Kommission.

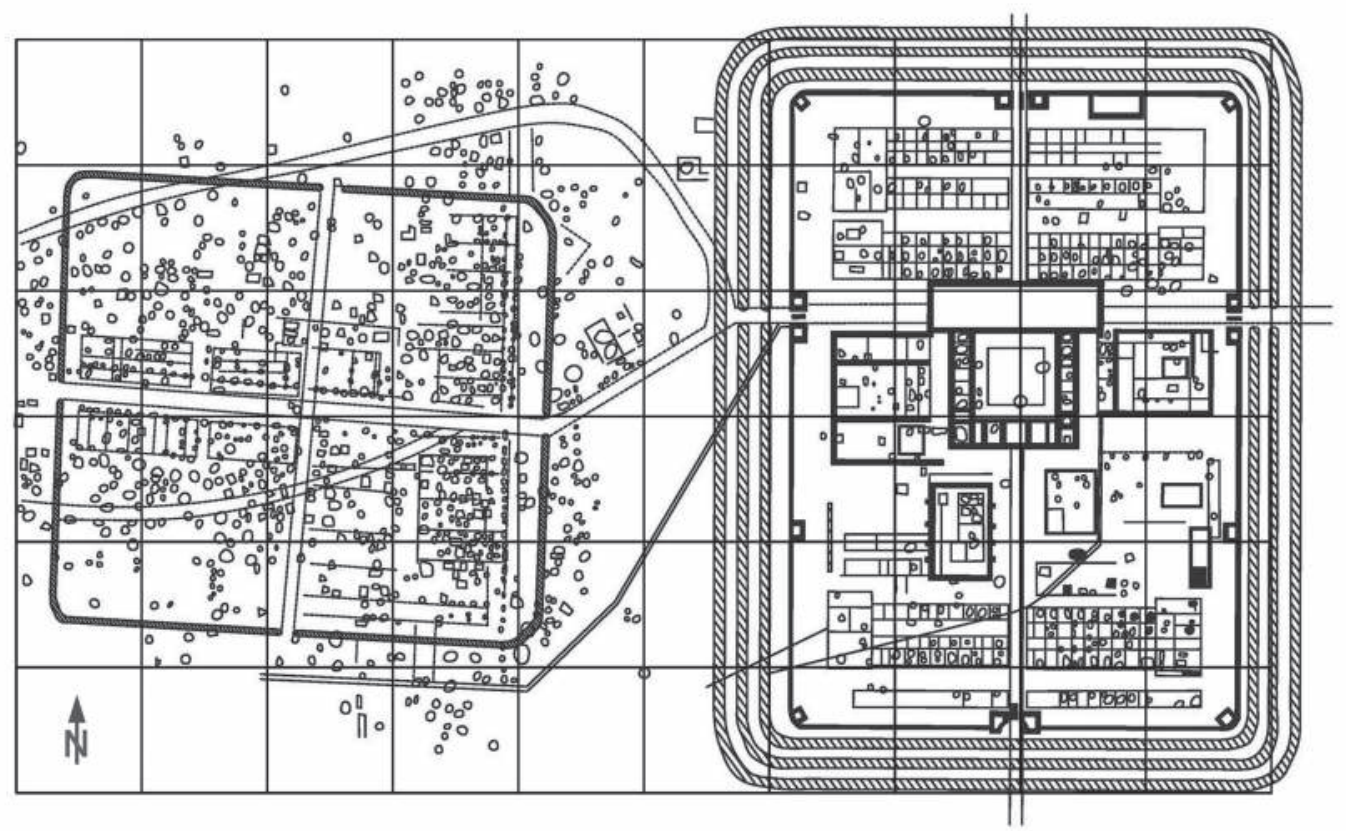

Figure 3: Airborne laser scan of the Roman Limes near KipfenbergPfahlbuck. Processing of data reveals a watch tower 14/77 (arrow). Digital terrain model, raster 0.5 $\mathrm{m}$, view from top, north is on top: Data processing by $\mathrm{H}$. Kerscher.

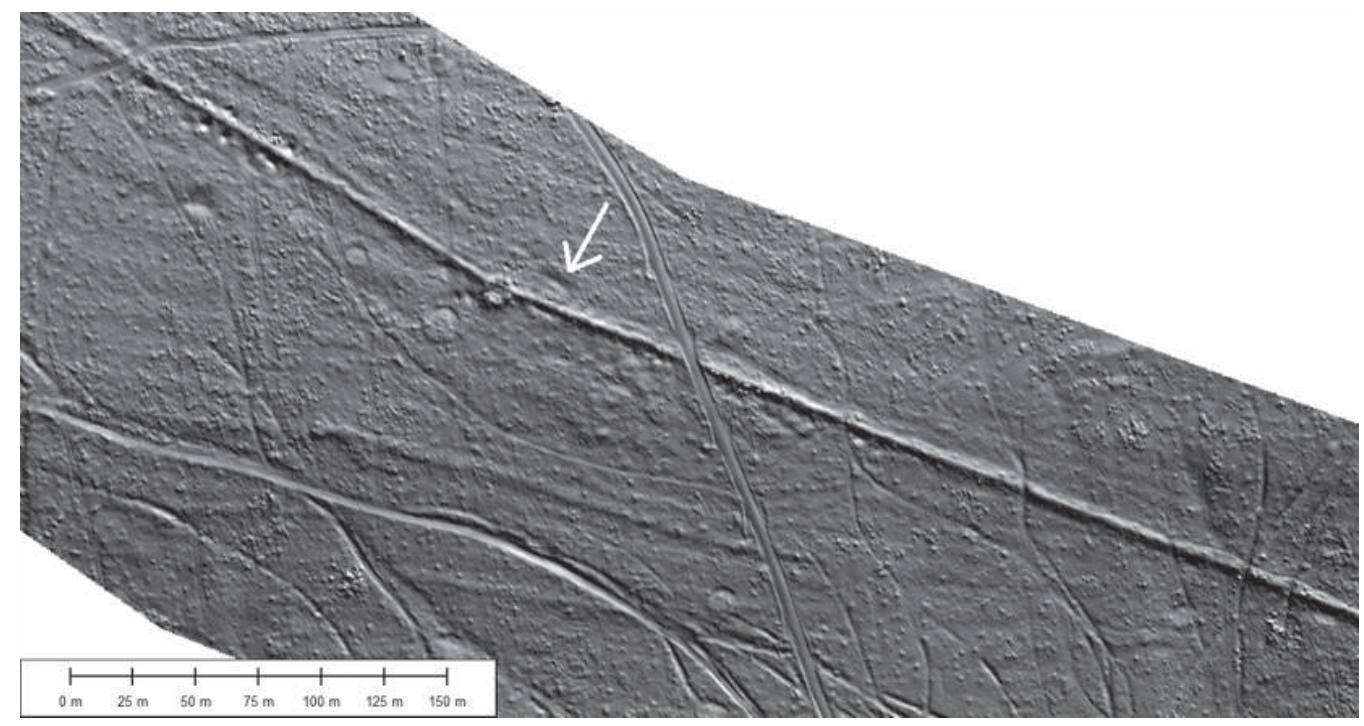

Geophysical prospecting, aerial archaeology and airborne laser scanning methods have become the sole and occasionally excellent non-destructive medium to recover, understand and continue archaeological research on these sites.

\section{References}

BECKER, H., 1999. Duo- and quadro-sensor configuration for high-speed/high resolution magnetic prospecting with caesium magnetometer. In Fassbinder, J. W. E., Irlinger, W. E., (dir.). Archaeological Prospection. Arbeitsh. Bayer. Landesamt f. Denkmalpflege, 108, München, 100-105.

Fabricius, E., Hettner, F. and Von Sarvey, O., 1894-1937. Der obergermanisch-raetische Limes des Römerreichs, Berlin, Leipzig, Heidelberg. 
FAssbinder, J. W. E., 2008. Neue Ergebnisse der geophysikalischen Prospektion am obergermanisch-raetischen Limes. Beiträge zum Welterbe Limes, 3: 155-171.
KersCher, H., 2008. Beobachtungen am Limes-Wachposten 14/77 auf dem Pfahlbuck bei Kipfenberg. Arch. Jahr Bayern 2007: 77-78. 